\title{
Fluoride concentration in mouth rinses marketed in Chile and Brazil, and a discussion regarding their legislations
}

\author{
Astrid Carolina VALDIVIA-TAPIA(a) \\ Juliana Nunes BOTELHO(b) \\ Rodrigo Andrés GIACAMAN(c) (iD \\ Cinthia Pereira Machado \\ TABCHOURY(a) \\ Jaime Aparecido CURY(a) \\ (a) UniversidadeEstadual de Campinas - \\ Unicamp, Piracicaba Dental School, \\ Department of Biosciences, Piracicaba, SP, \\ Brazil. \\ (b) University of Talca, Faculty of Health \\ Sciences, Department of Pediatric \\ Stomatology, Talca, Chile. \\ (c) University of Talca, Faculty of Health \\ Sciences, Department of Oral \\ Rehabilitation, Talca, Chile.
}

Declaration of Interests: The authors certify that they have no commercial or associative interest that represents a conflict of interest in connection with the manuscript.

Corresponding Author:

Jaime Aparecido Cury

E-mail: jcury@unicamp.br

hitps://doi.org/10.1590/1807-3107bor-2021.vol35.0083

Submitted: November 16, 2020

Accepted for publication: March 1, 2021

Last revision: June 12, 2021
Abstract: For fluoride to be effective in controlling caries, it should be bioavailable in commercial products, so that it can be released into the mouth in the products it contains. We chemically determined the available fluoride and $\mathrm{pH}$ in nine mouth rinses marketed in Chile, and eleven, in Brazil, and then discussed the legislation in force in both countries, regarding the anticaries potential of these oral hygiene products. The fluoride was analyzed with an ion-selective electrode (F-ISE), using the direct technique. The determinations were made in duplicate, and the results were expressed in ppm F ( $\mu \mathrm{g} \mathrm{F} / \mathrm{mL})$. The total fluoride concentration found in all the mouth rinses evaluated ranged from 94.7 to 233.5 ppm F, and closely matched what was declared by the manufacturers (100.0 to $226.2 \mathrm{ppm} \mathrm{F}$ ). However, some mouth rinses showed lower fluoride concentrations ( 90 and $180 \mathrm{ppm} \mathrm{F}$ ) in both countries. $\mathrm{A} \mathrm{Na}_{2} \mathrm{FPO}_{3}$-formulated mouth rinse was found only in Chile, with 216.8 ppm F as the $\mathrm{FPO}_{3}{ }^{2-}$ ion, and $4.9 \mathrm{ppm} \mathrm{F}$ as the $\mathrm{F}^{-}$. The findings show that fluoride was potentially bioavailable in all the mouth rinses evaluated. Regarding the national legislations, although the mouthwashes sold in Brazil comply with the Brazilian legislation, discrepancies were found for Chile. However, neither country had a legislation matching the best available evidence on fluoride mouthwash efficacy for caries control. Thus, some products with low fluoride concentrations (below 226 ppm F), or manufactured with a fluoride salt other than $\mathrm{NaF}\left(\mathrm{Na}_{2} \mathrm{FPO}_{3}\right)$ are being sold in the Brazilian and Chilean markets.

Keywords: Mouthwashes; Ion-Selective Electrodes; Fluorides; Sodium Fluoride.

\section{Introduction}

Dental caries is one of the most prevalent non-communicable diseases worldwide, affecting 2.5 billion people around the world. ${ }^{1}$ Fluoride is the most effective substance for reducing caries, and there are different available formats for community or individual use. ${ }^{2}$ Fluoride mouth rinses are over-the-counter products, and are available in different formulations on the worldwide market. ${ }^{3,4}$ According to the best scientific evidence, they should be formulated with $\mathrm{NaF}$ at the concentration of 230 ppm F. ${ }^{5}$ In addition, the fluoride in any oral 
hygiene product should be chemically soluble in the formulation as a minimum requirement for an anticaries effect.

For fluoride mouth rinses to claim anticaries potential, they must comply with national (local) or common market regulations. Brazil is one of the founding members of and participates in Mercosur, which has legislation in place on fluoride mouth rinses. Resolution Mercosur/GMC/RES. \#24/11 specifies that mouth rinses are cosmetic, and not therapeutic products. According to this legislation, different fluoride salts, such as sodium fluoride $(\mathrm{NaF})$, sodium monofluorophosphate $\left(\mathrm{Na}_{2} \mathrm{FPO}_{3}\right)$, and stannous fluoride $\left(\mathrm{SnF}_{2}\right)$, among others, may be added to mouth rinses, but the maximum total fluoride concentration must be at least $0.15 \%$. It also states that fluoride mouth rinses should not be used by children under 6 years of age, and should be under sanitary surveillance by the Agência Nacional de Vigilância Sanitária (Anvisa). ${ }^{6}$

In Chile, the products for oral hygiene are supervised by the National Institute of Public Health (ISP) of Chile's Ministry of Health (MINSAL). According to Chilean Decree \#239, mouth rinses are classified as specialty cosmetics, because of their risk of use. ${ }^{7}$ In 2018, Chilean Resolution Exemption 952 recommended that mouth rinses be formulated with $\mathrm{NaF}$ at concentrations of $0.05 \%$ (230 ppm F) or $0.2 \%(900$ ppm F $){ }^{8}$

No information is available on the fluoride content of commercial mouth rinses sold either in Chile or Brazil. Thus, the aim of the present study was to determine the fluoride concentration in mouth rinses marketed in both countries, and to discuss whether the products researched are in line with both the local legislation and the best available scientific evidence on the anticaries effect.

\section{Methodology}

\section{Sampling}

This exploratory study evaluated the fluoride concentration of 20 fluoridated mouth rinses (Table 1), nine from Chile (code A-I), and 11 from Brazil (codes J-T). They were purchased at different pharmacies and supermarkets from Talca, Chile, and from the cities of Limeira and Piracicaba, Brazil. These same brands are probably the most widely sold mouth rinses in both countries, because they are manufactured by multinational companies that control the market in both Brazil and Chile. They were purchased between May and June 2018, and $1-3$ bottles $(n=1-3)$ of each commercial brand were purchased. We intended to purchase three bottles of each brand from different stores, but were unfortunately unable to do this for all the mouthwash brands. The brands were coded for analysis, and the information declared on the label is shown in Table 1. Except for brand $\mathrm{H}$, all the mouth rinses were formulated with $\mathrm{NaF}$, and most with approximately $225 \mathrm{ppm}$ F. All the analyses were made in June 2018, within the expiration date of the products (July 2018 - November 2021).

\section{Sample preparation for analysis}

Figure illustrates the mouth rinse preparation for analysis with a fluoride ion-selective electrode (F-ISE) using the direct technique. The brands containing $\mathrm{NaF}$ were diluted 20 -fold in purified water, and a $1.0-\mathrm{mL}$ aliquot was buffered with the same volume of total ionic strength adjustment buffer (TISAB) II (1.0 M acetate buffer, $\mathrm{pH}$ 5.0, containing $1.0 \mathrm{M} \mathrm{NaCl}$ and $0.4 \%$ CDTA). Two analyses were made for the mouth rinse containing $\mathrm{Na}_{2} \mathrm{FPO}_{3}$ (Brand $\mathrm{H})$, because most fluoride is $\mathrm{FPO}_{3}{ }^{2-}$ ion, and only part is free fluoride ion $\left(\mathrm{F}^{-}\right)$, and ready to be analyzed by the electrode. $\mathrm{F}^{-}$was determined by mixing $0.25 \mathrm{~mL}$ of the $\mathrm{Na}_{2} \mathrm{FPO}_{3}$ mouth rinse with $1.0 \mathrm{~mL}$ of TISAB II, $0.5 \mathrm{~mL}$ of $1.0 \mathrm{M} \mathrm{NaOH}$, and 0.25 $\mathrm{mL}$ of $2.0 \mathrm{M} \mathrm{HCl}$. The $\mathrm{FPO}_{3}{ }^{2-}$ ion $+\mathrm{F}^{-}$(Total fluoride $=\mathrm{TF}$ ) was determined by diluting the mouth rinse 10 -fold in purified water. An aliquot of $0.25 \mathrm{~mL}$ of this dilution was mixed with $0.25 \mathrm{~mL} 2.0 \mathrm{M} \mathrm{HCl}$, and kept for $1 \mathrm{~h}$ at $45^{\circ} \mathrm{C}$ to hydrolyze the $\mathrm{FPO}_{3}{ }^{2-}$ ion, ${ }^{9}$ and to release $\mathrm{F}$-for detection by F-ISE. This mixture was neutralized with $0.5 \mathrm{~mL} 1.0 \mathrm{M} \mathrm{NaOH}$ and buffered with $1.0 \mathrm{~mL}$ of TISAB II, as described for toothpaste analysis. ${ }^{9}$ The fluoride concentration ( $\mathrm{ppm} \mathrm{F}$ ) as the $\mathrm{FPO}_{3}{ }^{2-}$ ion was calculated by subtracting $\mathrm{TF}$ from $\mathrm{F}^{-}$ (Figure). All the analyses were made in duplicate, and the variation coefficient (\%) was calculated as an indicator of reproducibility. 
Table 1. Mouthwash information declared on the label of the bottles.

\begin{tabular}{|c|c|c|c|c|c|c|}
\hline Code & Commercial name & Country & Manufacturer & $\begin{array}{l}\text { Type of } F \\
\text { declared }\end{array}$ & $\begin{array}{l}\text { F concentration } \\
\text { declared (ppm F) }\end{array}$ & $\mathrm{n}$ \\
\hline A & Colgate Plax Ice Infinity & Chile & Colgate & $\mathrm{NaF}$ & 225 & 3 \\
\hline B & Colgate Plax Kids & Chile & Colgate & $\mathrm{NaF}$ & 225 & 3 \\
\hline C & Colgate Plax Fresh Mint & Chile & Colgate & $\mathrm{NaF}$ & 225 & 3 \\
\hline $\mathrm{D}$ & Colgate Plax Soft Mint & Chile & Colgate & $\mathrm{NaF}$ & 225 & 3 \\
\hline $\mathrm{E}$ & Listerine Anticaries Zero Alcohol & Chile & Johnson \& Johnson & $\mathrm{NaF}$ & 220 & 3 \\
\hline $\mathrm{F}$ & Listerine Cuidado Total Zero & Chile & Johnson \& Johnson & $\mathrm{NaF}$ & 100 & 3 \\
\hline G & Vitis Orthodontic & Chile & Dentaid & $\mathrm{NaF}$ & 225 & 2 \\
\hline $\mathrm{H}$ & Vitis Sensible & Chile & Dentaid & $\mathrm{Na}_{2} \mathrm{FPO}_{3}$ & 226 & 3 \\
\hline I & Oral B Complete & Chile & Procter \& Gamble & $\mathrm{NaF}$ & 226 & 1 \\
\hline J & Sensodyne & Brazil & Glaxosmithkline & $\mathrm{NaF}$ & 217 & 2 \\
\hline K & Oral B complete & Brazil & Procter \& Gamble & $\mathrm{NaF}$ & 226 & 3 \\
\hline L & Colgate Total 12 & Brazil & Colgate & $\mathrm{NaF}$ & 225 & 3 \\
\hline M & Colgate Plax Ice Glacyal & Brazil & Colgate & $\mathrm{NaF}$ & 225 & 3 \\
\hline $\mathrm{N}$ & Colgate Luminous White XD & Brazil & Colgate & $\mathrm{NaF}$ & 225 & 3 \\
\hline O & Colgate OrthoGard & Brazil & Colgate & $\mathrm{NaF}$ & 180 & 1 \\
\hline $\mathrm{P}$ & Listerine defesa dos dentes e gengivas & Brazil & Johnson \& Johnson & $\mathrm{NaF}$ & 99.4 & 3 \\
\hline$Q$ & Listerine cuidado total zero & Brazil & Johnson \& Johnson & $\mathrm{NaF}$ & 100 & 3 \\
\hline R & Listerine Anticaries & Brazil & Johnson \& Johnson & $\mathrm{NaF}$ & 220 & 3 \\
\hline S & Cepacol crianças & Brazil & Sanofi & $\mathrm{NaF}$ & 226.2 & 1 \\
\hline $\mathrm{T}$ & Cepacol & Brazil & Sanofi & $\mathrm{NaF}$ & 226.2 & 1 \\
\hline
\end{tabular}

F: Fluoride; $\mathrm{NaF}$ : Sodium fluoride; $\mathrm{Na}_{2} \mathrm{FPO}_{3}$ : Sodium monofluorophosphate.

\section{Fluoride determination}

Two distinct calibration curves were plotted, one to analyze the mouthwashes with $\mathrm{NaF}$, and the other, those with $\mathrm{Na}_{2} \mathrm{FPO}_{3}$. The electrode for the $\mathrm{NaF}$ mouth rinses was calibrated with standard fluoride solutions ranging from 0.5 to $16.0 \mu \mathrm{g} \mathrm{F} / \mathrm{mL}$, prepared in TISAB II 50\% (v/v) $\left(\mathrm{r}^{2}=0.9999\right)$, and that of the $\mathrm{Na}_{2} \mathrm{FPO}_{3}$ mouth rinse, with standard fluoride solutions ranging from 0.0625 to $4.0 \mu \mathrm{g} \mathrm{F} / \mathrm{mL}$ in 0.25 $\mathrm{M} \mathrm{HCl}, 0.25 \mathrm{M} \mathrm{NaOH}$ and TISAB II at 50\% (v/v) $\left(r^{2}=0.9998\right)$, to determine both $\mathrm{F}^{-}$and total fluoride. The standard fluoride dilutions were obtained from a 100 ppm F solution prepared from $99.99 \%$ pure $\mathrm{NaF}$ (Sigma-Aldrich, St Louis, MO, USA). The accuracy of the analysis was validated using a standard fluoride solution (Orion 940907, Thermo Scientific), with the coefficient of variation from triplicates of $-1.1 \%$ and $-0.8 \%$, respectively, for the $\mathrm{NaF}$ and the $\mathrm{Na}_{2} \mathrm{FPO}_{3}$ calibration curves.

The readings in $\mathrm{mV}$ of the sample solutions were converted to fluoride concentration using the Microsoft Office Excel 2016 software program. The values of the duplicates from each mouth rinse bottle were averaged, and the mean of each product was calculated and expressed as ppm $\mathrm{F}$ ( $\mu \mathrm{g} \mathrm{F} / \mathrm{mL}$ ). The variation coefficient (VC) of the duplicates for all the samples was $0.9 \%$. An F-ISE (ORION 96-09 SZ2-15176; ORION Research, Boston, MA, USA), coupled to an ion analyzer (Thermo Scientific Orion VersaStar), was used to perform all the analyses.

\section{pH determination}

The $\mathrm{pH}$ values of the mouth rinses were determined with a pH-electrode (Procyon \#002453), coupled to a potentiometer (Procyon 002455 18W, model SA 720), using an aliquot from each bottle. The $\mathrm{pH}$ meter was calibrated with standard pH 4.0 (ORION 910460) and 7.0 buffers (ORION 910107). For mouth rinses with $\mathrm{pH}$ higher than 7.0, the $\mathrm{pH}$ was rechecked with a calibration made with standard buffers 7.0 (ORION 910107) and 10.0 (ORION 910110). 


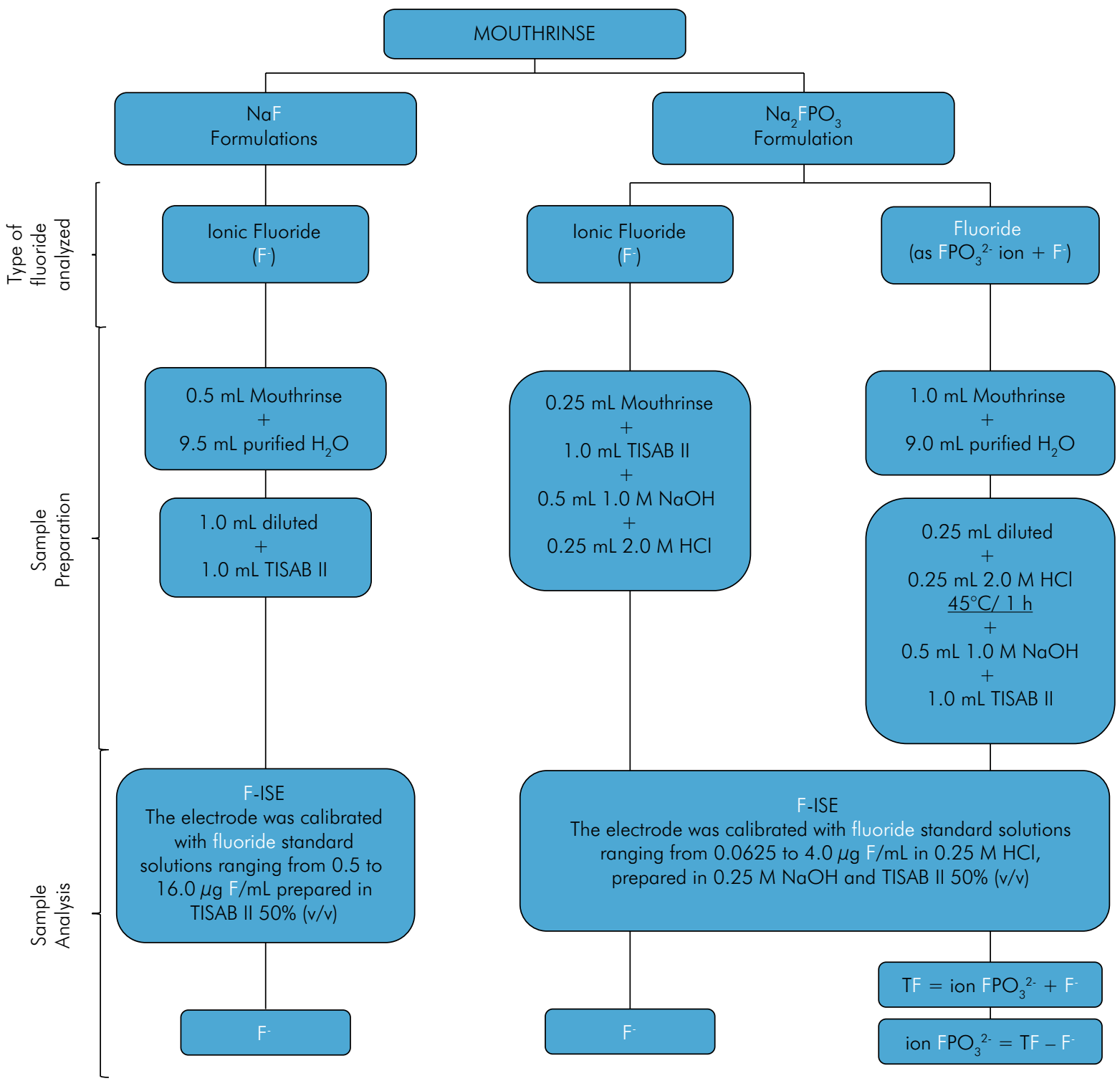

Figure. Diagram of $\mathrm{NaF}$ and $\mathrm{Na}_{2} \mathrm{FPO}_{3}$ mouth rinse sample preparation for fluoride analysis with F-ISE.

\section{Legislations on fluoride mouth rinses}

We researched the legislations on mouthwashes for both countries by searching the websites of the respective Ministries of Health of Brazil and of Chile. The Brazilian legislation is the same used in all MERCOSUR countries. Table 2 describes the main data obtained.

\section{Statistical analysis}

When 2-3 bottles of each brand were analyzed for fluoride concentration, a descriptive analysis was carried out based on the mean and the standard deviation (SD) found. The concentrations found were compared with the fluoride concentration declared on the labeling by the manufacturer. The same procedure was followed for determining $\mathrm{pH}$, but the $\mathrm{pH}$ of the products was not specified by the manufacturers.

\section{Results}

The fluoride concentration found in the NaFevaluated mouth rinses ranged from 94.7 to 233.5 ppm F (Table 3). In the mouth rinse formulated with 
Table 2. Specifications regarding the Brazilian and Chilean fluoride mouthwash regulations.

\begin{tabular}{|c|c|c|c|c|c|c|c|c|}
\hline Country & Regulations & $\begin{array}{c}\text { Supervisory } \\
\text { entity }\end{array}$ & Year & $\begin{array}{c}\text { Classification } \\
\text { of products }\end{array}$ & $\begin{array}{c}\text { Concentration } \\
\text { of Fluoride }\end{array}$ & $\begin{array}{c}\text { Fluoride Salts } \\
\text { Allowed }\end{array}$ & $\begin{array}{c}\text { Age } \\
\text { recommended }\end{array}$ & $\begin{array}{l}\mathrm{pH} \text { of the } \\
\text { product }\end{array}$ \\
\hline Brazil & $\begin{array}{c}\text { Resolution } \\
\text { Mercosul (R) } \\
\text { /GMC/RES. } \\
N^{\circ} 24 / 11\end{array}$ & Anvisa & 2012 & $\begin{array}{l}\text { Cosmetic } \\
\text { products }\end{array}$ & $\begin{array}{l}\text { Maximum } \\
\text { total fluoride } \\
\text { concentration } \\
\text { must be } \\
0.15 \%\end{array}$ & $\begin{array}{l}\text { Sodium fluoride } \\
\text { (NaF), sodium } \\
\text { monofluorophosphate } \\
\left(\mathrm{Na}_{2} \mathrm{FPO}_{3}\right) \text {, stannous } \\
\text { fluoride }\left(\mathrm{SnF}_{2}\right) \\
\text { among others }\end{array}$ & $\begin{array}{c}>6 \text { years of } \\
\text { age }\end{array}$ & Undeclared \\
\hline Chile & $\begin{array}{c}\text { Decree } \\
\text { No. } 239 \\
\text { and } 2018 \\
\text { Resolutions } \\
\text { Exempt } 952\end{array}$ & $\begin{array}{c}\text { ISP } \\
\text { MINSAL }\end{array}$ & $2010 / 2018$ & $\begin{array}{c}\text { Special } \\
\text { cosmetics } \\
\text { products }\end{array}$ & $\begin{array}{l}\text { Daily use } \\
0.05 \% \\
\text { (230 ppm F) } \\
\text { or weekly } \\
\text { use } 0.2 \% \\
\text { (900 ppm F) }\end{array}$ & $\begin{array}{l}\text { Sodium fluoride } \\
\qquad(\mathrm{NaF})\end{array}$ & $\begin{array}{c}>6 \text { years of } \\
\text { age }\end{array}$ & Undeclared \\
\hline
\end{tabular}

*Agência Nacional de Vigilância Sanitária (Anvisa), National Institute of Public Health (ISP) of the Ministry of Health of Chile (MINSAL).

$\mathrm{Na}_{2} \mathrm{FPO}_{3}(\mathrm{H}), 4.9 \mathrm{ppm}$ was found as the $\mathrm{F}$ ion, and $216.8 \mathrm{ppm} \mathrm{F}$ as the $\mathrm{FPO}_{3}{ }^{2-}$, for a total fluoride value of 221.7 ppm F (Table 3). The fluoride concentrations of all mouth rinses were very close to those declared by the manufacturers, irrespective of that established by the legislations of either country.

The $\mathrm{pH}$ values found ranged from 4.26 to 7.66 (Table 3). The manufacturers of neither country declared the $\mathrm{pH}$ on the label of the bottles, bearing in mind that the legislation of neither country requires this information.

\section{Discussion}

The findings showed that the majority of mouth rinses found in the Chilean and the Brazilian markets (Table 1) were formulated with $\mathrm{NaF}$, except for brand $\mathrm{H}$, formulated with $\mathrm{Na}_{2} \mathrm{FPO}_{3}$, and marketed only in Chile (Table 2). The percentage difference between the concentrations found, and those declared by the manufacturers was very low on average (mean $-0.7 \%$; $\mathrm{n}=20$ brands). Although the fluoride concentrations found match those declared on the product bottles, disparities were found between each country's legislation and the anticaries potential of these oral hygiene products, as discussed below.

Thus, the different fluoride concentrations for all the mouthwashes bought in Brazil (Table 3) agree with the Brazilian legislation (Table 2), ${ }^{6}$ because none contained more than 1500 ppm F, the maximum allowed. However, in brands $\mathrm{O}, \mathrm{P}$ and $\mathrm{Q}$, the fluoride concentrations found were lower than $230 \mathrm{ppm} \mathrm{F}$, the concentration accepted as effective in reducing caries. ${ }^{5}$ Therefore, the claim stated on the mouth rinse label concerning "caries prevention" is misleading, because Brazilian legislation classifies fluoride mouth rinses as cosmetic, but they are actually being sold as therapeutic anticaries oral hygiene products. Based on this paradox, we recommend that the Brazilian legislation on fluoride mouth rinses be revised, and that the concentrations indicate $230 \mathrm{ppm} \mathrm{F}$ and 900 ppm F for daily and weekly use, respectively. ${ }^{5}$ The fluoride concentrations in mouth rinses marketed in Brazil have already been evaluated in the past ${ }^{10,11}$, when these products were under Brazilian legislation, but not under MERCOSUR rules. In the past, the Brazilian legislation established that a daily fluoride mouth rinse should contain 230 ppm F; nevertheless, mouth rinses with 90 ppm F and 500 ppm F were found in the market.

Unlike the research that has been conducted into Brazilian products, ours was the first to investigate Chilean mouth rinses. In Chile, the MINSAL ${ }^{8}$ legislative norm (Table 2) establishes that fluoride mouth rinses should be formulated with $\mathrm{NaF}$ at concentrations of $0.05 \%$ (230 ppm F) for daily use, or $0.2 \%$ (900 ppm F) for weekly use, in agreement with the best available scientific evidence for caries prevention. ${ }^{5}$ However, our findings showed that $\mathrm{F}$ and $\mathrm{H}$ mouth rinses did not comply with the Chilean norm. Mouth rinse F was formulated with $\mathrm{NaF}$, but contained only 96.5 ppm F. In mouth rinse $H$, 
Table 3. Mean $\left( \pm S D\right.$ ) fluoride concentration (ppm F) expected and found as the fluoride ion and the $\mathrm{FPO}_{3}^{2}$ ion, and $\mathrm{pH}$ of the mouthwashes ( $\mathrm{n}=3$; except mouth rinses $\mathrm{G}$ and $\mathrm{J}, \mathrm{n}=2 ; \mathrm{I}, \mathrm{O}, \mathrm{S}$ and $\mathrm{T}, \mathrm{n}=1$ ).

\begin{tabular}{|c|c|c|c|c|}
\hline \multirow{3}{*}{ Code } & \multirow{3}{*}{ Expected } & \multicolumn{2}{|c|}{ Fluoride (ppm F) } & \multirow{3}{*}{$\mathrm{pH}$} \\
\hline & & \multicolumn{2}{|c|}{ Found as } & \\
\hline & & $\mathrm{F}-$ & $\mathrm{FPO}_{3}{ }^{2-}$ & \\
\hline A & 225 & $223.4 \pm 1.4$ & - & $5.28 \pm 0.00$ \\
\hline B & 225 & $228.7 \pm 0.9$ & - & $5.27 \pm 0.00$ \\
\hline C & 225 & $225.5 \pm 3.6$ & - & $5.23 \pm 0.01$ \\
\hline D & 225 & $230.7 \pm 6.4$ & - & $5.22 \pm 0.02$ \\
\hline$E$ & 220 & $213.2 \pm 2.3$ & - & $4.28 \pm 0.00$ \\
\hline $\mathrm{F}$ & 100 & $96.5 \pm 2.0$ & - & $4.37 \pm 0.00$ \\
\hline G & 225 & $233.5 \pm 5.1$ & - & $4.62 \pm 0.01$ \\
\hline $\mathrm{H}$ & 226 & $4.9 \pm 1.4$ & $216.8 \pm 3.5$ & $5.76 \pm 0.00$ \\
\hline I & 226 & 223.7 & - & 5.79 \\
\hline J & 217 & $224.6 \pm 4.3$ & - & $6.65 \pm 0.01$ \\
\hline K & 226 & $224.8 \pm 3.4$ & - & $5.30 \pm 0.24$ \\
\hline $\mathrm{L}$ & 225 & $229.4 \pm 2.4$ & - & $4.63 \pm 0.01$ \\
\hline M & 225 & $227.0 \pm 7.1$ & - & $5.26 \pm 0.00$ \\
\hline$N$ & 225 & $222.9 \pm 4.1$ & - & $7.66 \pm 0.03$ \\
\hline O & 180 & 189.4 & - & $4.45 \pm 0.00$ \\
\hline $\mathrm{P}$ & 99.4 & $95.4 \pm 0.2$ & - & $4.35 \pm 0.07$ \\
\hline$Q$ & 100 & $94.7 \pm 0.9$ & - & $4.34 \pm 0.00$ \\
\hline$R$ & 220 & $209.1 \pm 8.0$ & - & $4.26 \pm 0.00$ \\
\hline $\mathrm{S}$ & 226.2 & 206.8 & - & 7.11 \\
\hline $\mathrm{T}$ & 226.2 & 226.1 & - & 7.35 \\
\hline
\end{tabular}

F-:ion fluoride; $\mathrm{FPO}_{3}^{2-:}$ ion fluorophosphate.

we found a total of $221.7 \mathrm{ppm} \mathrm{F}$, but the fluoride salt used was $\mathrm{Na}_{2} \mathrm{FPO}_{3}$, not $\mathrm{NaF}$. In addition, the claims on the label of these products state "anticaries" or "caries prevention," hence suggesting that these products have a therapeutic effect. Although there is evidence that toothpastes formulated with $\mathrm{Na}_{2} \mathrm{FPO}_{3}$ are indeed effective in reducing caries, ${ }^{12}$ mouthwashes formulated with this type of fluoride salt have not been clinically tested. If the anticaries mechanism of mouth rinses depends on the reactivity of fluoride with enamel-dentine surfaces, it is not expected that the $\mathrm{Na}_{2} \mathrm{FPO}_{3}$ in this product be effective, because, similar to toothpaste, the $\mathrm{FPO}_{3}^{-2}$ ion must first be hydrolyzed in the $\mathrm{F}$ ion. ${ }^{13}$

The discussion on the fluoride content of mouth rinses available in the market, and the legislation that regulates their use does not apply solely to
Brazil and Chile. Similarly, mouthwashes with low fluoride concentration $(<0.05 \% \mathrm{NaF})$ or with $\mathrm{Na}_{2} \mathrm{FPO}_{3}$ have also been reported in Saudi Arabia and Russia. ${ }^{14,15}$ The regulation set down by the Food and Drug Administration (FDA) in the United States establishes that mouthwashes must contain an active agent for caries control, based on $\mathrm{NaF}$ at $0.05 \%$ or $0.2 \%$, and a $\mathrm{pH}$ of about $7.0 .{ }^{16}$ In the United Kingdom, it is recommended that daily fluoride mouth rinses contain $230-1350$ ppm F, and be prescribed for adults and children aged 8 years or older, with no specification for the type of fluoridated salt. ${ }^{17}$ For countries in the European Union, the Scientific Committee on Health and Environmental Risks (SCHER) states that dental products (including mouthwashes) should contain fluoride at different concentrations up to $1500 \mathrm{ppm}$. 
There is no information on the type of fluoride salt used in these commercial products. ${ }^{18}$ Latin American signatories of Mercosur follow the EU legislation. In 2012, the recommendations by different countries regarding fluoride mouth rinses were assessed, and concluded that the guidelines for the different signatory nations must provide consistent recommendations, despite the limited evidence on anticaries efficacy. However, additional data are required to establish an international guideline, such as the optimal concentration of fluoride at the time of use, and further research on oral fluoride reservoirs and on the effect of these reservoirs over several weeks' time. ${ }^{19}$ Our study proposes that relevant changes be made in the Brazilian and Chilean legislations, which could further impact other countries into modifying mouth rinses to make them more effective against caries, consistent with the best available scientific evidence.

Regarding $\mathrm{pH}$ evaluation, we evaluated this variable even though the Brazilian and Chilean legislations do not require that mouth rinses have an optimum $\mathrm{pH}$, or that manufacturers declare the $\mathrm{pH}$ of their products on the label. Irrespective of the type of fluoride product used, the chemical reaction between fluoride and enamel is greater at a low $\mathrm{pH} .{ }^{20}$ Therefore, the manufacturer could justify a product with lower fluoride concentration than the conventional $230 \mathrm{ppm} F$ by claiming that the low $\mathrm{pH}$ of his product is required for this very purpose. However, although mouthwashes E, F, G, L, P, Q, R and O had a pH lower than 5.0 (Table 2), only F, P and Q were formulated with low fluoride concentration. In the past, a commercial mouth rinse with $\mathrm{pH} 4.2$ was found in the Brazilian market, but it had the conventional concentration of $230 \mathrm{ppm} \mathrm{F}^{11}$ Moreover, although Zero et al. (2004) showed in situ that a mouth rinse with low fluoride concentration (100 ppm F) and low $\mathrm{pH}$ was as effective for enamel remineralization as the conventional product at $230 \mathrm{ppm} \mathrm{F}$, data on reduced demineralization are unknown. ${ }^{21}$ Accordingly, the importance of $\mathrm{pH}$ on enamel-dentine reactivity, and the anticaries effect of mouth rinses warrants further study.

Furthermore, our data showed that fluoride was found in a chemically soluble form in all the mouth rinses evaluated. Unlike toothpaste, ${ }^{22}$ all fluoride in mouth rinses is potentially bioavailable when released in the oral cavity during rinsing. Nevertheless, it is known that some substances, such as detergents used in mouthwash formulations, may interfere with the effect of fluoride. ${ }^{23}$ Thus, tests should be conducted to ascertain the fluoride bioavailability of commercial mouth rinses with enamel-dentine as an indicator of the anticaries potential of these oral hygiene products. ${ }^{24}$

One limitation of the present study was that the mouthwash samples analyzed were purchased only in two cities of São Paulo State, in Brazil, and in one city in Chile. However, most of the mouthwashes are manufactured by multinational companies with reach across the entire market of both countries, over a relatively simultaneous time period.

\section{Conclusion}

The findings showed that some mouth rinses in both the Chilean and Brazilian markets presented fluoride concentrations below $226 \mathrm{ppm} \mathrm{F}$, or were formulated with fluoride salts other than $\mathrm{NaF}$, such as $\mathrm{Na}_{2} \mathrm{FPO}_{3}$, thus compromising the putative anticaries effect, in disagreement with the best available scientific evidence. Based on the findings, more rigorous sanitary surveillance is strongly suggested to investigate this type of product in both countries.

\section{Acknowledgments}

The authors would like to thank Mr. José Alfredo Da Silva from the Oral Biochemistry Laboratory of the Piracicaba Dental School, Unicamp, Piracicaba, SP, Brazil, for his technical assistance, and Funcamp for its funding. The first author received the "University of Talca Dental Clinics Center Scholarship" from the University of Talca, as an undergraduate student. During her graduate training program at the Piracicaba Dental School (FOP-Unicamp), she received a scholarship from Capes. This publication was based on a thesis submitted by the first author to FOP-Unicamp, to fulfill the requirements for a Master's degree in dentistry (concentration in cariology). 
- Fluoride concentration in mouth rinses marketed in Chile and Brazil, and a discussion regarding their legislations

\section{References}

1. Kassebaum NJ, Smith AG, Bernabé E, Fleming TD, Reynolds AE, Vos T, et al. Global, regional, and national prevalence, incidence, and disability-adjusted life years for oral conditions for 195 countries, 1990-2015: a systematic analysis for the global burden of diseases, injuries, and risk factors. J Dent Res. 2017 Apr;96(4):380-7. https://doi.org/10.1177/0022034517693566

2. Tenuta LM, Cury JA. Laboratory and human studies to estimate anticaries efficacy of fluoride toothpastes. Monogr Oral Sci. 2013;23:108-24. https://doi.org/10.1159/000350479

3. Rugg-Gunn A, Bánóczy J. Fluoride toothpastes and fluoride mouthrinses for home use. Acta Med Acad. 2013 Nov;42(2):168-78. https://doi.org/10.5644/ama2006-124.84

4. Twetman S, Keller MK. Fluoride rinses, gels and foams: an update of controlled clinical trials. Caries Res. 2016;50 Suppl 1:38-44. https://doi.org/10.1159/000439180

5. Marinho VC, Chong LY, Worthington HV, Walsh T. Fluoride mouthrinses for preventing dental caries in children and adolescents. Cochrane Database Syst Rev. 2016 Jul;7(7):CD002284. https://doi.org/10.1002/14651858.CD002284.pub2

6. Agência Nacional de Vigilância Sanitária. Resolução de Diretoria Colegiada - RDC Nº3, de 18 de janeiro de 2012. Aprova o Regulamento Técnico "Listas de substâncias que os produtos de higiene pessoal, cosméticos e perfumes não devem conter exceto nas condições e com as restrições estabelecidas" e dá outras providências. Diário Oficial União. 2012 Jan.

7. Minsterio de Salud (CL). Decreto 239, de 20 de setembro de 2002 [cited 2020 oct 16]. Aprueba reglamento del sistema nacional de control de cosmeticos. Available from: https://www.leychile.cl/N? $i=211455 \& f=2010-11-04 \& p=$

8. Ministério de Salud (CL). Norma General Técnica N 105, de 27 de octubrede 2008. Norma de uso de fluoruros em la prevención odontológica. Available from: https://diprece.minsal.cl/wp-content/uploads/2019/02/norma-de-fluoruros_conResEx_V2019.pdf. Access: 2020 Oct 16.

9. Cury JA, Oliveira MJ, Martins CC, Tenuta LM, Paiva SM. Available fluoride in toothpastes used by Brazilian children. Braz Dent J. 2010;21(5):396-400. https://doi.org/10.1590/S0103-64402010000500003

10. Rodrigues LKA, Dalcico R, Gomes VE, Zanin ICJ, Nascimento MM, Duarte S. [Fluoride concentration in mouthwashes marketed in Brazil and the use of ion-specific electrode]. RPG. 2002;9(2):142-8. Portuguese.

11. Delbem AC, Sassaki KT, Castro AM, Pinto LM, Bergamaschi M. Assement of the fluoride concentration and $\mathrm{pH}$ in different mouthrinses on the brazilian market. J Appl Oral Sci. 2003 Dec;11(4):319-23. https://doi.org/10.1590/S1678-77572003000400008

12. Marinho VC, Higgins JP, Sheiham A, Logan S. Fluoride toothpastes for preventing dental caries in children and adolescents. Cochrane Database Syst Rev. 2003;(1):CD002278. https://doi.org/10.1002/14651858.CD002278

13. Tenuta LM, Del Bel Cury AA, Tabchoury CP, Moi GP, Silva WJ, Cury JA. Kinetics of monofluorophosphate hydrolysis in a bacterial test plaque in situ. Caries Res. 2010;44(1):55-9. https://doi.org/10.1159/000279466

14. Aldrees AM, AlBeshri SS, AISanie IS, Alsarra IA. Assessment of fluoride concentrations in commercially available mouthrinses in central Saudi Arabia. Saudi Med J. 2014 Oct;35(10):1278-82.

15. Reshetnyak VY, Nesterova OV, Admakin OI, Dobrokhotov DA, Avertseva IN, Dostdar SA, et al. Evaluation of free and total fluoride concentration in mouthwashes via measurement with ion-selective electrode. BMC Oral Health. 2019 Nov;19(1):251. https://doi.org/10.1186/s12903-019-0908-0

16. Federal Dental Association. Code of Federal Regulations: Title 21. Food and drugs, Chapter I: Food and drug administration. Department of Health and Human Services: Subchapter D - Drugs for human use [Internet]. Washngton, DC: U.S. Food \& Drug administration; 2019 [cited 2020 Oct 27]. Available from: https://www.accessdata.fda.gov/scripts/cdrh/cfdocs/cfcfr/CFRSearch.cfm?CFR Part $=355 \&$ showFR $=1 \&$ subpartNode $=21: 5 \cdot 0.1 \cdot 1 \cdot 28.2$

17. NHS. Fluoride [Internet]. NHS; 2018 [cited 2020 Oct 27]. Available from: https://www.nhs.uk/conditions/fluoride/

18. European Commission. Scientific Committee on Health and Environmental Risks. Critical review of any new evidence on the hazard profile, health effects, and human exposure to fluoride and the fluoridating agents of drinking water [Internet]. 16 May 2011 [cited 2020 Oct 27]. Available from: https://ec.europa.eu/health/scientific_committees/environmental_risks/docs/ scher_o_139.pdf

19. Pitts N, Duckworth RM, Marsh P, Mutti B, Parnell C, Zero D. Post-brushing rinsing for the control of dental caries: exploration of the available evidence to establish what advice we should give our patients. Br Dent J. 2012 Apr;212(7):315-20. https://doi.org/10.1038/sj.bdj.2012.260

20. Tabchoury CP, Pierobon CN, Cury JA. Concentration and bioavailability of fluoride in mouthrinses prepared in dispensing pharmacies. J Appl Oral Sci. 2005 Mar;13(1):41-6. https://doi.org/10.1590/S1678-77572005000100009

21. Zero DT, Zhang JZ, Harper DS, Wu M, Kelly S, Waskow J, et al. The remineralizing effect of an essential oil fluoride mouthrinse in an intraoral caries test. J Am Dent Assoc. 2004 Feb;135(2):231-7. https://doi.org/10.14219/jada.archive.2004.0157 
22. Coelho CS, Cury JA, Tabchoury CP. Chemically soluble fluoride in $\mathrm{Na}_{2} \mathrm{FPO}_{3} / \mathrm{CaCO}_{3}$-Based Toothpaste as an indicator of fluoride bioavailability in saliva during and after toothbrushing. Caries Res. 2020;54(2):185-93. https://doi.org/10.1159/000506439

23. Franco EM, Cury JA. Effect of Plax prebrushing rinse on enamel fluoride deposition. Am J Dent. 1994 Apr;7(2):119-21.

24. Moi GP, Tenuta LM, Cury JA. Anticaries potential of a fluoride mouthrinse evaluated in vitro by validated protocols. Braz Dent J. 2008;19(2):91-6. https://doi.org/10.1590/S0103-64402008000200001 